\title{
Effects of Gibberelic Acid (GA3) and Berry Thinning on Güz Gülü, Özer Beyazı, Süleymanpaşa Beyazı and Tekirdağ Misketi Seedless Table Grape Cultivars
}

\author{
Cengiz Özer ${ }^{1 *}\left(\mathbb{D}\right.$, Onur Ergönül ${ }^{1}$ \\ ${ }^{1}$ Viticulture Research Institute, Tekirdağ, Turkey.
}

How to cite: Özer, C., \& Ergönül, O. (2021). Effects of gibberelic acid (GA $)$ and berry thinning on Güz Gülü, Özer Beyazı, Süleymanpaşa Beyazı and Tekirdağ Misketi Seedless table grape cultivars. Viticulture Studies (VIS), 1(1): 1 - 10. https://doi.org/10.52001/vis.2021.1

\section{Article History:}

Received: 09.02.2021

Accepted: 03.05.2021

First online: 07.05.2021

\section{Corresponding Author}

ozercengiz@tarimorman.gov.tr

\begin{abstract}
This study was carried out to determine the effects of berry thinning and gibberellin $\left(\mathrm{GA}_{3}\right)$ on cluster and fruit quality components of Güz Gülü, Özer Beyazı, Süleymanpaşa Beyazı, and Tekirdağ Misketi seedless table grape cultivars. Gibberellic acid $\left(\mathrm{GA}_{3}\right)$, a total of $40 \mathrm{ppm}$, was sprayed to thinned and unthinned clusters at the stages of full bloom and 3-5 mm berry size. Berries were thinned with the removal of one-third of the basal part of clusters. $\mathrm{GA}_{3}$ increased the size of Güz Gülü berries when it was either treated solely or together with berry thinning. Maturity indices increased at $\mathrm{GA}_{3}$ sprayed and thinned Güz Gülü clusters compared to the control. Color $L$ and Color b values of Güz Gülü grapes were highest with gibberellin application. While $\mathrm{GA}_{3}$ increases the berry weight in Süleymanpaşa Beyazı grapes, additional berry thinning is necessary to obtain larger berries. However, the attachment between berry and pedicel of gibberellin sprayed to Süleymanpaşa grapes weakened significantly. The berries of gibberellin-treated Tekirdağ Misketi grapes were heaviest. While the width of the berries did not change with the applications, the length of the berries was highest when only $\mathrm{GA}_{3}$ was applied to Tekirdağ Misketi grapes.
\end{abstract}

\section{Introduction}

Cluster and berry quality characteristics are as important as productivity in table grape cultivation. Cluster and berry thinnings, gibberellin sprayings, and girdling are necessary practices, especially for attractive appearance in terms of well filled and mid or big size clusters, larger berries especially in seedless varieties, and enhancement of color of the berries. The reactions to these practices may vary according to the grape variety, ecology and training systems. Growers demand detailed information about the best procedures specific to especially in novel grape cultivars. In addition to the studies like rootstock compatibility, the reacts of especially new seedless grape cultivars to the hormones, girdling, and thinning applications for larger berries should be determined.

Large berries, attractive color, unique aroma and taste, crisp texture, ideal bunch shape, loose clusters, early or late ripening are desired in the table grape sector in addition to high fruitfulness. Even the berries are generally small, seedless grape varieties dominate the table grape market because of eating quality. Intensive irrigation and fertilization programs, gibberellin, cluster and berry thinning, and girdling are applied to increase the berry size as much as possible in widely grown seedless Sultanina table grapes. Abundance of new alternative grape cultivars on the market is beneficial to competitiveness. Most of the novel grape cultivars are seedless with superior features in terms of early or late harvest time, berry color, muskat aroma, and extended shelf life. Large berry without any external application is desirable trait for new seedless grape cultivars, but it may generally not be possible in stenospermic grapes because of premature 
abortion seed development (Ponce et al., 2000). The influences of the cultural practices on berry and cluster quality components affecting consumer preference should be determined based on each grape cultivar.

Cell division and elongation is induced with gibberellin, especially at seedless varieties. Gibberellin dose and application stages may vary according to cultivar, ecology, and growing system. Gibberellin as 10 to $15 \mathrm{ppm} \mathrm{GA} 3$ was effective for thinning and 80 to $120 \mathrm{ppm}$ for the larger berries of Thompson Seedless, while adequate $\mathrm{GA}_{3}$ levels are 5 to $7.5 \mathrm{ppm}$ for thinning and 20 to $30 \mathrm{ppm}$ to increase berry size for Flame Seedless in Chili (Pérez-Harvey, 1994). The berries are thinned at Thompson Seedless by a 10-15 ppm gibberellic acid spray at full bloom in Israel. Repetitive $20-40 \mathrm{mg} \mathrm{L}^{-1}$ gibberellic acid sprays with seven to 10 day intervals increase the berry size (Lavee, 1994). Sultana is treated twice with $10 \mathrm{mg} \mathrm{L}^{-1}$ gibberellic acids in South Africa (Orth, 1994). Gibberellin is applied to reduce berry set at bloom to Thompson Seedless and Flame Seedless in California. Two sprays of gibberellin for berry enlargement, one at fruit set and the other five to seven days later, are commonly applied to Thompson Seedless, Flame Seedless, and Perlette grapes (Jensen, 1994). Gibberellin is used intensively in Sultanina vineyards at the Aegean Region of Turkey. Ateş and Karabat (2006), recommend two sprays of 20 ppm $\mathrm{GA}_{3}$ to the $5-10 \mathrm{~cm}$ and $15-20 \mathrm{~cm}$ inflorescences; single application of $20 \mathrm{ppm} \mathrm{GA} 3$ during flowering (50-80\%) and two sprays of 40 ppm $\mathrm{GA}_{3}$ at 4-5 mm berry size.

The size of berries and clusters was increased with gibberellin sprays at bloom and berry set at several previous studies (Khanduja and Chaturvedi, 1979; Saad et al., 1979; Thilak, 1983; Wali et al., 1990; Sing et al., 1994; Colapietra et al., 1995a and b; El-Hodairi et al., 1995; Uzun and Ceyhan, 1995; Qadir et al., 1998; Samancı, 1998; Kara and Ecevit, 1998; Tian et al., 2011; Kukali et al., 2014; Fayziev et al., 2020; Akhmedova, 2020; Tavşan et al., 2020). The gibberellin sprays 10 days after berry set increased berry size of Reçel Üzümü grapes. Gibberellin treatments as $10+20+20$ ppm $\mathrm{GA}_{3}$ and $20+40+40$ ppm GA $A_{3}$ at full bloom, berry set, and ten days after berry set respectively gave the highest berry weights (Özer et al., 2008). It has been determined in several previous studies that sugar accumulation in berries can decrease with gibberellin and harvest is delayed (Jensen et al., 1994; Uzun and Ceyhan, 1995; Colapietra et al., 1996; Samancl, 1998). On the other hand, high maturity indices have been determined due to the reduction in total acidity at gibberellin sprayed to grapes (Moti, 1971; Thilak, 1983; Sing et al.,1994; Colapietra et al., 1996; Tian et al., 2011). But, sugar content in Reçel Üzümü grapes did not differ significantly in gibberellin or girdling treatments (Özer et al., 2008). Enhancement at the size of berries and clusters, heavier and compact cluster, and advanced maturity were monitored with 10 or 20 ppm GA3 sprayings at both full bloom and berry set stages of Tekirdağ Misketi grapes (Ergönül et al., 2015). Gibberellin increased the berry drops in some previous studies (Badr and Ramming, 1994; Jensen et al., 1994). On the other hand, the unexpected event was observed, such as berry attachment to the pedicel of Thompson Seedless grapes being increased with gibberellin and berry shatter decreased (Retamales and Cooper, 1993). Grape clusters became looser with gibberellin sprays before or after the berry set (Sing et al., 1994; El-Hodairi et al., 1995). Gibberellin can cause insufficient coloring (Özer et al., 2012) and reduce anthocyanin content of grapes (ChangHoo et al., 1996).

Berry or cluster thinning treatments influence the source/sink ratio resulting in less crop load and more qualified grapes with improved photosynthetic assimilation (Reynolds et al., 1994). Table grapes are hand thinned to attain uniform, medium-sized, loose clusters of uniformly large, perfect berries with a characteristic color, pleasing flavor, and good texture. Growers prefer different styles of berry thinning. Partial removal of clusters or berries is made at one time or several times after the berry set. The level of the berry thinning must be synchronized with genotype and crop load (Jensen, 1994; Liuni et al., 1994; Orth, 1994). The size of berries and clusters generally increases with a combination of gibberellin and berry thinning (Yadav and Pandey, 1974; Mor, 1983; Colapietra et al., 1995a). High levels of berry thinning reduce bunch weight and make the bunches looser and straggly (Roberto et al., 2017; Han et al., 2019). Berry thinning increases berry weight and soluble solids (Dardeniz, 2014; Roberto et al., 2017), anthocyanins, total phenols 
(Han et al., 2019), especially at the 50\% level (Nangia and Bakhshi, 1971). Different types of thinning had no titratable acidity of berries at Black Star table grape cv. (Roberto et al., 2017), while $1 / 3$ tipping decreased titratable acidity at Cardinal grapes in another study (Dardeniz, 2014). Tartaric and malic acid contents of Red Globe were mostly influenced by the clusterberry thinning treatment after veraison and Alphonse Lavalleé accumulated the highest tartaric acid and malic acid in both the girdled/thinned and the cluster-berry thinned vines (Keskin et al., 2013).

The goal of this study was to examine the effects of gibberellin and berry thinning application on Güz Gülü, Özer Beyazı, Süleymanpaşa Beyazı, and Tekirdağ Misketi grape cvs. that had been released by Tekirdağ Viticulture Research Institute.

\section{Material and Methods}

This study was carried out on a 15-yearold vineyard located in the Tekirdağ Viticultural Research Institute in 2016. The scions of the grape cultivars had been grafted on Kober 5BB. The distances between the rows and within the rows were 3.0 and $1.50 \mathrm{~m}$, respectively. Trunk heights were $65 \mathrm{~cm}$ for bilateral Guyot pruned vines. Shoots from canes bearing 6 to 8 buds were trained vertically. The cultural practices were uniform for the experimental vines. The grape cultivars in the study and their characteristics are as follows.

Güz Gülü: Rose colored berries are seedless and picked in the late season with low sugar content. The weight of the berries reaches up to 6-7 $\mathrm{g}$ without any extra application. Loose and short or medium-sized clusters hold up well in cold storage.

Özer Beyazl: Late season grapes are seedless and yellow-green color and the average weight of the berries is $6.0 \mathrm{~g}$ while someones can reach up to $10 \mathrm{~g}$ without hormone application. Loose clusters in conical shape are mediumsized.

Süleymanpaşa Beyazı: Grapes mature in the late season, clusters are large-sized and 500 and $700 \mathrm{~g}$ in weight. The color of the round berries is yellow-green, and the seedless berries are 3-4 $\mathrm{g}$ in weight. The vigor and fertility of the vines are high.

Tekirdağ Misketi: Maturing is in mid-early season, berries are yellow-green color, seedless, and muscat flavor. Clusters are $300-400 \mathrm{~g}$ in weight and fertility is high at cane pruned vines.

The treatments in the experiment were 1control, 2- Gibberellic Acid $\left(G_{3}\right)$, and 3Combination of $\mathrm{GA}_{3}$ and berry thinning. Same amount of water to that gibberellin applications was sprayed to the control bunches on the same days. A total of $40 \mathrm{ppm} \mathrm{GA}_{3}$ were sprayed to the experimental clusters. The individual clusters were hand sprayed with $20 \mathrm{mg} \mathrm{L}^{-1}$ gibberellin (Hek-Gibb ${ }^{\circledR}$ tablets containing $1 \mathrm{~g} \mathrm{GA}_{3}$ ) at full bloom and 3-5 mm berry stages, in total $40 \mathrm{ppm}$ $\mathrm{GA}_{3}$ to run off while protecting all other parts of the vine. An adjuvant, Sylibom (ONC) organic

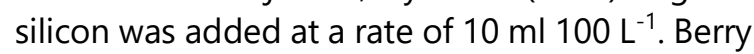
thinning was performed at gibberellin applied bunches by removing the third one of the basal part cluster at the 3-5 mm berry size stage.

The effects of the treatments on the cluster and berry quality components and the maturity of the grapes had been determined.

The experimental design was completely randomized parcels with ten replications. Each replication resembled one treated cluster. The differences between treatments were revealed by paired comparison through with t-test of the data. The data of the two treatments were subjected to a t-test and above 95 percent significance accepted as an important difference.

The parameters to determine the influence of treatments were berry width, berry length, berry weight, cluster width, cluster length, , cluster compactness, total soluble solids (TSS), titratable acidity (TA), maturity index (TSS/TA), berry skin color, berry removal force, and berry crushing resistance. The compactness of the clusters was determined according to the 1 (very loose) - 5 (very compact) scale (Çelik, 1998). Selected ten berries from different parts of each cluster were used to determine berry dimensions and berry weights, at harvest. The juice of twenty berries was used to measure soluble solids content and titratable acidity. Total soluble solids in the juice of these berries was measured with a temperature-compensated hand refractometer. Titratable acidity as tartaric acid content was determined by titrating a $10 \mathrm{ml}$ juice with $0.1 \mathrm{~N} \mathrm{NaOH}$ to $\mathrm{pH}$ 8.1. The skin color of the ten berries of Güz Gülü grapes was determined as color point $\left(L^{*}, a^{*}, b^{*}\right)$ with Konika-Minolta CM-5 device (Pathare et al., 
2012 ). The modified digital balance was used to determine berry removal force and berry crushing resistance. Twenty berries were placed on the test platform longitudinally and the pressure was applied to the equatorial zone until berry crushing. The fixed value on the screen of the balance was recorded. Afterward, twenty berries (pedicels attached) were placed on the platform vertically to determine berry removal force and fixed force at the time of the berry detachment from the pedicel was recorded.

\section{Results and Discussion}

The effects of $\mathrm{GA}_{3}$ or $\mathrm{GA}_{3}$ + berry thinning on cluster and berry quality components of Güz Gülü grapes are in Table 1. Cluster width did not change, but a cluster length decreased to 21.5 and $19.6 \mathrm{~cm}$ at $\mathrm{GA}_{3}$ and $\mathrm{GA}_{3}$ +berry thinning treatments respectively. Tipping at the base part of the cluster, naturally resulted in the decrease of cluster length as an expected result. $\mathrm{GA}_{3}$ increased berry size as alone or combined with berry thinning. The typical effect of gibberellin for larger berries, which has been demonstrated in many previous studies (Khanduja and Chaturvedi, 1979; Saad et al., 1979; Thilak, 1983; Wali et al., 1990; Sing et al., 1994; Colapietra et al., 1995a and 1995b; El- Hodairi et al., 1995; Uzun and Ceyhan, 1995; Qadir et al., 1998; Samancı, 1998; Kara and Ecevit, 1998; Tian et al., 2011; Kukalı et al., 2014, Fayziev et al., 2020), has also been shown again in this grape cultivar. Total acidity of the berries decreased with both
$\mathrm{GA}_{3}$ and $\mathrm{GA}_{3}$ +berry thinning while TSS at harvest increased with only $\mathrm{GA}_{3}$ + berry thinning treated vines compared to control, from 16.20 ${ }^{\circ}$ Brix to 17.24 Brix. The increase in TSS with additional berry thinning can be explained by the decrease in the number of berries accumulating sugar. Therefore, the enhancer application of maturity index compared to the control was $\mathrm{GA}_{3}$ + berry thinning. However, with additional berry thinning to gibberellin application, there was no difference compared to only $\mathrm{GA}_{3}$ application.

The crushing resistance of the berries was higher at larger berries with $\mathrm{GA}_{3}+$ berry thinning applications. The parallel result was at gibberellin sprayed Flame seedless before bloom (ElHammady et al, 1998). The correlation between berry weight and resistance to crushing is significant, according to Mattheou et al., 1995 and Özer and Kiracı, 2002. The reason for higher resistance to crushing of the berries may be an increase of berry size with $\mathrm{GA}_{3}$ and $\mathrm{GA}_{3}$ plus thinning in our study. The applications had no effect on the pedicel and berry attachment. Inefficient treatments on berry removal force in this study are in contradiction with some previous studies concerning the results that attachment strength with gibberellin (Samancl, 1998; Özer et al., 2002. The strength of attachment between berry and pedicel is proportional to cellulose content of stem and pedicel increasing with gibberellin dozes (Fidan et al., 1981).

Interaction between gibberellin and berry thinning was found to have an effect on the berry

Table 1. Effect of $G A_{3}$ and berry thinning on fruit quality and color points $\left(L^{*}, a^{*}, b^{\star}\right)$ of Güz Gülü table grape

\begin{tabular}{|c|c|c|c|c|c|c|c|}
\hline & $\begin{array}{l}\text { Cluster width } \\
\qquad(\mathrm{cm})\end{array}$ & $\begin{array}{l}\text { Cluster } \\
\text { length } \\
(\mathrm{cm})\end{array}$ & $\begin{array}{c}\text { Cluster } \\
\text { compactness }\end{array}$ & $\begin{array}{c}\text { Berry weight } \\
\text { (g) }\end{array}$ & $\begin{array}{l}\text { Berry width } \\
\quad(\mathrm{cm})\end{array}$ & $\begin{array}{l}\text { Berry } \\
\text { length } \\
(\mathrm{cm})\end{array}$ & $\begin{array}{c}\text { Total soluble } \\
\text { solids (TSS) } \\
\left({ }^{\circ} \text { Brix }\right)\end{array}$ \\
\hline Control & $18.70^{a}$ & $28.30^{a}$ & $3.80^{a}$ & $5.80^{b}$ & $2.15^{b}$ & $2.07^{b}$ & $16.20^{b}$ \\
\hline $\mathrm{GA}_{3}$ & $17.80^{a}$ & $21.50^{b}$ & $4.40^{a}$ & $7.60^{a}$ & $2.38^{a}$ & $2.23^{a}$ & $15.78^{b}$ \\
\hline \multirow[t]{2}{*}{$\begin{array}{l}\mathrm{GA}_{3}+\text { berry } \\
\text { thinning }\end{array}$} & $17.20^{a}$ & $19.60^{b}$ & $2.30^{b}$ & $6.92^{a}$ & $2.28^{a}$ & $2.14^{\mathrm{a}}$ & $17.24^{a}$ \\
\hline & $\begin{array}{c}\text { Titratable } \\
\text { acidity (TA) } \\
\left(\mathrm{g} 100 \mathrm{ml}^{-1}\right)\end{array}$ & TSS/TA & $\begin{array}{l}\text { Resistance to } \\
\text { crushing } \\
\text { (g) }\end{array}$ & $\begin{array}{c}\text { Berry } \\
\text { removal } \\
\text { force }(g)\end{array}$ & $L^{*}$ & $a^{*}$ & $b^{*}$ \\
\hline Control & $0.40^{a}$ & $40.40^{b}$ & $1054.30^{b}$ & $375.20^{a}$ & $28.31^{b}$ & $5.68^{a}$ & $1.53^{\mathrm{ab}}$ \\
\hline $\mathrm{GA}_{3}$ & $0.36^{b}$ & $44.32^{a b}$ & $1440.80^{a}$ & $355.35^{a}$ & $32.63^{a}$ & $3.74^{\mathrm{a}}$ & $2.60^{a}$ \\
\hline $\begin{array}{l}\mathrm{GA}_{3}+\text { berry } \\
\text { thinning }\end{array}$ & $0.36^{b}$ & $48.61^{a}$ & $1295.25^{a}$ & $361.20^{a}$ & $27.82^{b}$ & $4.68^{a}$ & $0.86^{b}$ \\
\hline
\end{tabular}

The values with different letters in a column are significantly different $(P<0.05)$ according to paired comparison through with t-test of the data. 
removal force for pedicel attachment to berries of Reçel Üzümü grapes at a similar study. Contrary to our study, removal of one-third of the basal part of clusters increased the berry removal force compared to unthinned and nongibberellin sprayed vines (Özer et al., 2012). Gibberellin did not show a significant tendency to increase berry-pedicel connection in Reçel Üzümü in another study (Özer et al., 2005) conducted before similar to our study, but it tended to increase removal force especially at higher doses in the Güz Üzümü cultivar. Gibberellin showed a significant increase with 32.63 compared to the control in $L$ value measurements representing the black value with zero and the brightest white with 100; in other words, the color of the berries slightly bleached. This trend indicates that care should be taken in the application of gibberellins in Güz Gülü vines sometimes having insufficient color problems depending on the product load and climatic condition. The similar $L$ values of $\mathrm{GA}_{3}+$ berry thinning and control grapes indicate the negative effect of this hormone on color can be eliminated with additional thinning. Although there was no statistically significant difference between the treatments in terms of color (a) points representing the spectrum from green to red; It is noteworthy that gibberellin gives the farthest value from red, even if it is numerically. On the $b$ axis of the blue-yellow components, the value representing more yellow color intensity (2.60) was in gibberellin application. In a similar study (Akhmedova, 2020), the improvement of color by the increased dose of gibberellin applications in Lotus and Kishmish Rozovy seedless grape varieties is inconsistent with the ineffectiveness of gibberellin on red color in our study.

The fact that gibberellin causes insufficient coloring in grapes in the red seedless table variety (Özer et al., 2012) supports our findings in this direction. Similarly, gibberellic acid application after the full bloom has led to a decrease in anthocyanin content of Kyoho grapes (ChangHoo et al, 1996). Berry thinning with gibberellin spraying will be beneficial to produce larger and uniform colored berries at Güz Gülü grapes.

The width of cluster did not change at Özer Beyazı cultivar, but length diminished with berry thinning because of the removal part of clusters as an expected result (Table 2). There were differences in berry weight than the control $(4.51 \mathrm{~g})$ with $\mathrm{GA}_{3}(5.10 \mathrm{~g})$ and $\mathrm{GA}_{3}$ +berry thinning $(5.44 \mathrm{~g})$ treatments. Larger berries were the cause of the compact clusters. Berry width increased with only $\mathrm{GA}_{3}+$ berry thinning; berry lengths were higher with both $\mathrm{GA}_{3}$ and $\mathrm{GA}_{3}+$ berry thinning. There was a similar effect on maturity components for the treatments as augmentation of maturity indices with the acceleration of acidity reduction and sugar accumulation. Profitability can be much more, considering the positive effects of these treatments on maturity improvement. Gibberellin increased the berry removal force to $306.72 \mathrm{~g}$ when it was combined with berry thinning. Higher berry crushing resistance values of treatments than the control is the other

Table 2. Effect of $\mathrm{GA}_{3}$ and berry thinning on fruit quality of Özer Beyazı table grape.

\begin{tabular}{|c|c|c|c|c|c|c|}
\hline & $\begin{array}{c}\text { Cluster width } \\
(\mathrm{cm})\end{array}$ & $\begin{array}{c}\text { Cluster length } \\
(\mathrm{cm})\end{array}$ & $\begin{array}{c}\text { Cluster } \\
\text { compactness }\end{array}$ & $\begin{array}{c}\text { Berry weight } \\
\text { (g) }\end{array}$ & $\begin{array}{l}\text { Berry width } \\
(\mathrm{cm})\end{array}$ & $\begin{array}{l}\text { Berry length } \\
(\mathrm{cm})\end{array}$ \\
\hline Control & $15.00^{a}$ & $26.78^{a}$ & $3.56^{b}$ & $4.51^{b}$ & $1.91^{b}$ & $2.19^{b}$ \\
\hline $\mathrm{GA}_{3}$ & $15.89^{a}$ & $26.11^{a}$ & $5.11^{\mathrm{a}}$ & $5.10^{a}$ & $1.93^{a b}$ & $2.30^{a}$ \\
\hline \multirow[t]{2}{*}{$\begin{array}{l}\mathrm{GA}_{3}+\text { berry } \\
\text { thinning }\end{array}$} & $17.56^{\mathrm{a}}$ & $18.67^{b}$ & $5.11^{\mathrm{a}}$ & $5.44^{\mathrm{a}}$ & $2.00^{a}$ & $2.29^{a}$ \\
\hline & $\begin{array}{c}\text { Total soluble } \\
\text { solids (TSS) } \\
\text { ('Brix) }\end{array}$ & $\begin{array}{l}\text { Titratable acidity } \\
\text { (TA) }\left(\mathrm{g} 100 \mathrm{ml}^{-1}\right)\end{array}$ & TSS/TA & $\begin{array}{l}\text { Resistance to } \\
\text { crushing } \\
\text { (g) }\end{array}$ & $\begin{array}{c}\text { Berry } \\
\text { removal } \\
\text { force }(\mathrm{g})\end{array}$ & \\
\hline Control & $14.78^{b}$ & $0.55^{a}$ & $26.98^{b}$ & $1290.39^{b}$ & $160.44^{b}$ & \\
\hline $\mathrm{GA}_{3}$ & $16.78^{a}$ & $0.36^{b}$ & $46.76^{a}$ & $1719.83^{a}$ & $204.27^{a b}$ & \\
\hline $\begin{array}{l}\mathrm{GA}_{3}+\text { berry } \\
\text { thinning }\end{array}$ & $16.32^{a}$ & $0.33^{b}$ & $50.11^{a}$ & $1635.39^{a}$ & $306.72^{a}$ & \\
\hline
\end{tabular}

The values with different letters in a column are significantly different $(P<0.05)$ according to paired comparison through with $t$-test of the data. 
evidence of the berry firmness. As a result, gibberellin alone may be sufficient to increase the berry size of this cultivar. The stronger attachment between pedicel and berry with thinning can increase the durability in transit and cold storage conditions.

Gibberellin caused a statistically significant rise in both cluster width $(15.50 \mathrm{~cm})$ and cluster length (27.00) compared to control in Süleymanpaşa Beyazı grapes (Table 3). The clusters containing larger berries were more compact at gibberellin (5.17) and gibberellin combined with berry thinning (5.83). Berry thinning with gibberellin increased the berry weight to $5.1 \mathrm{~g}$ and it was statistically superior to both control and Gibberellin. Although gibberellin increases the berry weight in this cultivar, additional berry thinning is necessary because of the larger berries. The highest berry width $(1.97 \mathrm{~cm})$ and berry length $(2.23 \mathrm{~cm})$ were measured at thinned and gibberellin sprayed bunches. Another alternative would be higher doses of Gibberellin for larger berries. Sugar accumulation in the berries had not been influenced, while the treatments reduced the acidity of the fruit juice. This resulted in an increase in maturity index in grapes treated with gibberellin compared to control grapes. The firmness of the berries was higher at thinned and gibberellin sprayed clusters $(2118.00 \mathrm{~g}$ berry crushing resistance) than control and gibberellin treated clusters. The attachment between pedicel and berry weakened with the applications, significant reduction to $215.25 \mathrm{~g}$ was especially for alone gibberellin while additional berry thinning strengthened the

Table 3. Effect of $\mathrm{GA}_{3}$ and berry thinning on fruit quality of Süleymanpaşa Beyazı table grape

\begin{tabular}{|c|c|c|c|c|c|c|}
\hline & $\begin{array}{c}\text { Cluster width } \\
(\mathrm{cm})\end{array}$ & $\begin{array}{l}\text { Cluster length } \\
(\mathrm{cm})\end{array}$ & $\begin{array}{c}\text { Cluster } \\
\text { compactness }\end{array}$ & $\begin{array}{c}\text { Berry Weight } \\
\text { (g) }\end{array}$ & $\begin{array}{l}\text { Berry width } \\
(\mathrm{cm})\end{array}$ & $\begin{array}{l}\text { Berry length } \\
(\mathrm{cm})\end{array}$ \\
\hline Control & $11.66^{b}$ & $20.16^{b}$ & $4.17^{b}$ & $3.45^{c}$ & $1.75^{b}$ & $1.88^{b}$ \\
\hline $\mathrm{GA}_{3}$ & $15.5^{a}$ & $27.00^{a}$ & $5.17 \mathrm{ab}$ & $3.87^{b}$ & $1.81^{b}$ & $1.97^{b}$ \\
\hline \multirow[t]{2}{*}{$\begin{array}{l}\mathrm{GA}_{3}+\text { berry } \\
\text { thinning }\end{array}$} & $13.67^{a b}$ & $12.66^{c}$ & $5.83^{a}$ & $5.10^{a}$ & $1.97^{a}$ & $2.23^{a}$ \\
\hline & $\begin{array}{c}\text { Total soluble } \\
\text { solids (TSS) } \\
\left({ }^{\circ} \text { Brix }\right)\end{array}$ & $\begin{array}{l}\text { Titratable } \\
\text { acidity (TA) } \\
\left(\mathrm{g} 100 \mathrm{ml}^{-1}\right)\end{array}$ & TSS/TA & $\begin{array}{l}\text { Resistance to } \\
\text { crushing } \\
\text { (g) }\end{array}$ & $\begin{array}{c}\text { Berry } \\
\text { removal } \\
\text { force }(g)\end{array}$ & \\
\hline Control & $22.30^{a}$ & $0.49^{a}$ & $46.40^{b}$ & $1540.67^{b}$ & $332.42^{a}$ & \\
\hline $\mathrm{GA}_{3}$ & $20.93^{a}$ & $0.41^{b}$ & $51.96^{a}$ & $1618.67^{b}$ & $215.25^{b}$ & \\
\hline $\begin{array}{l}\mathrm{GA}_{3}+\text { berry } \\
\text { thinning }\end{array}$ & $20.25^{a}$ & $0.41^{b}$ & $49.96^{a b}$ & $2118.00^{a}$ & $289.00 \mathrm{ab}$ & \\
\hline
\end{tabular}

The values with different letters in a column are significantly different $(\mathrm{P}<0.05)$ according to paired comparison through with t-test of the data.

Table 4. Effect of $\mathrm{GA}_{3}$ and berry thinning on fruit quality of Tekirdağ Misketi table grape.

\begin{tabular}{|c|c|c|c|c|c|c|}
\hline & $\begin{array}{l}\text { Cluster width } \\
(\mathrm{cm})\end{array}$ & $\begin{array}{c}\text { Cluster length } \\
(\mathrm{cm})\end{array}$ & $\begin{array}{c}\text { Cluster } \\
\text { compactness }\end{array}$ & $\begin{array}{l}\text { Berry weight } \\
\text { (g) }\end{array}$ & $\begin{array}{l}\text { Berry width } \\
(\mathrm{cm})\end{array}$ & $\begin{array}{l}\text { Berry length } \\
(\mathrm{cm})\end{array}$ \\
\hline Control & $16.10^{a}$ & $22.90^{a}$ & $5.90^{a}$ & $2.98^{a b}$ & $1.47^{a}$ & $1.83^{c}$ \\
\hline $\mathrm{GA}_{3}$ & $14.55^{\mathrm{a}}$ & $19.10^{b}$ & $5.60^{a}$ & $3.03^{a}$ & $1.51^{\mathrm{a}}$ & $2.14^{a}$ \\
\hline \multirow[t]{2}{*}{$\begin{array}{l}\mathrm{GA}_{3}+\text { berry } \\
\text { thinning }\end{array}$} & $16.10^{a}$ & $16.20^{b}$ & $6.20^{a}$ & $2.64^{b}$ & $1.45^{a}$ & $2.04^{b}$ \\
\hline & $\begin{array}{c}\text { Total soluble } \\
\text { solids (TSS) } \\
\left({ }^{\circ} \text { Brix }\right) \\
\end{array}$ & $\begin{array}{c}\text { Titratable } \\
\text { acidity (TA) } \\
\left(\mathrm{g} 100 \mathrm{ml}^{-1}\right) \\
\end{array}$ & TSS/TA & $\begin{array}{l}\text { Resistance to } \\
\text { crushing } \\
\text { (g) }\end{array}$ & $\begin{array}{l}\text { Berry removal } \\
\text { force }(\mathrm{g})\end{array}$ & \\
\hline Control & $16.32^{a}$ & $0.58^{b}$ & $28.28^{b}$ & $770.50^{b}$ & $243.70^{a}$ & \\
\hline $\mathrm{GA}_{3}$ & $18.24^{a}$ & $0.48^{c}$ & $38.19^{a}$ & $1147.55^{a}$ & $174.15^{b}$ & \\
\hline $\begin{array}{l}\mathrm{GA}_{3}+\text { berry } \\
\text { thinning }\end{array}$ & $16.06^{a}$ & $0.67^{a}$ & $24.52^{b}$ & $1021.20^{a}$ & $168.10^{b}$ & \\
\hline
\end{tabular}

The values with different letters in a column are significantly different $(P<0.05)$ according to paired comparison through with t-test of the data. 
linkage.

The cluster length of Tekirdağ Misketi grapes reduced to 19.10 and $16.20 \mathrm{~cm}$ with gibberellin and gibberellin plus berry thinning respectively (Table 4). The density of the naturally compact clusters of Tekirdağ Misketi did not change with the treatments. The difference between applications in terms of berry weight was significant, the heaviest berries were in the gibberellin application alone. The widths of the berries were similar; while the berry length was highest with $2.14 \mathrm{~cm}$ in $\mathrm{GA}_{3}$ application alone. Although the berry length at $\mathrm{GA}_{3}+$ berry thinning treatment (2.04) was close to $\mathrm{GA}_{3}$ numerically, it was classified as a subgroup statistically. However, both applications provided a significant increase in berry length compared to the control. The soluble solids of the grapes did not change, but more mature grapes were harvested with the lowest acidity $\left(0.48 \mathrm{~g} 100 \mathrm{ml}^{-1}\right)$ in $\mathrm{GA}_{3}$ application. The maturity index value at control grapes was 28.28 and it increases to 38.19 at $\mathrm{GA}_{3}$ sprayed grapes. $\mathrm{GA}_{3}$ may allow harvest earlier in this mid-early cultivar. The increase in the crushing resistance of the berries seems like a positive aspect, while the decrease in the berry removal force of the berries in applications can be considered negatively according to the control.

The effects of treatments on quality parameters were generally evaluated in this section. It can be said that gibberellin increased only the width of the clusters of Süleymanpaşa Beyazı grapes. Berry thinning by removing some part of the cluster caused an expected decrease in cluster lengths at all grape cultivars. Even the increased berry dimensions did not change the cluster appearance; so the clusters of Güzü Gülü grapes were looser with gibberellin plus berry thinning. Akhmedova (2020) reports that clusters are less compact with gibberellin applications. As a similar result, the increase in the berry mass with gibberellin did not compensate for looser appearance in the berry thinned Black Star grapes (Roberto et al., 2017). Thinned and gibberellin sprayed clusters of Özer Beyazı and Süleymanpaşa Beyazı were more compact, probably because of the larger berries. Similarly, the cluster densities at gibberellin or gibberellin + forchlorfenuron treated Sultanina grapes were higher than the control (Tavşan et al., 2020).

The main goal of this study was to improve berry size and it was achieved at Güzü
Gülü and Özer Beyazı grapes by gibberellin or a combination gibberellin and berry thinning. While the berry weight of Süleymanpaşa grapes was improved with gibberellin, the berry dimensions increased statistically only with gibberellin plus berry thinning. The reacts of Süleymanpaşa Beyazı to these treatments are indicative of the necessity of berry thinning or higher doses of gibberellin. Comparably, the size of the berries of Black Star table grapes increased with berry thinning applications (Roberto et al., 2017). The berry weight and length of Tekirdağ Misketi grapes increased with gibberellin. The increase in the length of the oblong berries with gibberellin is consistent with the findings of Akhmedova, (2020) at novel seedless grapes. Similarly, Tavşan et al. (2020) stated that gibberellin sprays at berry set and 2$3 \mathrm{~mm}$ berry size increased the berry weight and dimensions of Sultanina grapes. While the sugar accumulation in the grapes was not affected by the applications in Süleymanpaşa Beyazı and Tekirdağ Misketi grapes, it has been accelerated with the applications in Güz Gülü and Özer Beyazı grapes. Similarly, to our findings at Güz Gülü and Özer Beyazı, Kukalı et al. (2014) reported the sugar accumulation in gibberellin treated grapes increased by $0.6-4.2 \%$ and 18 days' acceleration of the maturity. These findings did not support some previous studies (Jensen et al., 1994; Uzun and Ceyhan, 1995; Tavşan et al., 2020) that indicate gibberellin delays sugar accumulation in berries. According to the study (Roberto et al., 2017) on the effects of berry thinning treatments at various phenologic stages, total soluble solids and maturation index of Black Star table grapes were superior to the control. Soluble solids of Perlette (Nangia and Bakhshi, 1971) and Centennial Seedless (Colapietra et al., 1995 a) grapes were similarly increased by thinning. The reduction trend of total acidity with gibberellin was monitored at all cultivars like several previous studies. Gibberellin promoted maturity in all varieties and a higher maturity level than gibberellin has been achieved with additional berry thinning in the Güz Gülü. It should be noted that the main factor to increase maturity index is the significant decrease in the total acid content. Different berry thinning levels at gibberellin and CPPU sprayed Summer Black grapes reduced the total acidity and increased the sugar content (Yong et al., 2016). Han et al. 
(2019) reported the enhancement of sugar accumulation and berry color, while the inverse change of titratable acidity in proportion to thinning levels at Cabernet Sauvignon. The reason for these actions was stated as the higher activity of cell wall invertase (CWI) and soluble acid invertase (SAI) of thinned clusters, which was associated with upregulated transcription

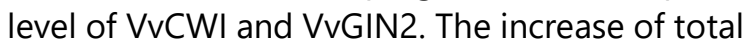
acidity at some organically grown and clusterberry thinned grapes (Keskin et al., 2013) contradicts the reducing trend in our study. However, it should be noted thinning had made at veraison in that study and it is a later phase than our study. It was observed that different levels of berry thinning via three tipping treatments did not influence the cluster width in the Cardinal grapes, but increased it in the Uslu grapes (Dardeniz, 2014). Cluster compactness significantly increased by the tipping level, and clusters were tighter as the level increased. Larger berries and lower total acidity in two grape cultivars and advanced maturity of Cardinal grapes support the findings of our study. The firmness of the berries from the treated grapes was higher than control depending on increase berry size especially berry width. The attachment between pedicel and berry was stable at all treatment for Güz Gülü; but it weakened with gibberellin applications at Tekirdağ Misketi ve Süleymanpaşa Beyazı grapes. Berry thinning can eliminate this weakness at gibberellin applied Özer Beyazı and Süleymanpaşa Beyazı grapes.

\section{Conclusion}

$\mathrm{GA}_{3}$ +berry thinning is beneficial to produce larger and uniform colored berries at Güz Gülü grapes. $\mathrm{GA}_{3}$ application alone may be sufficient to increase the berry size of Özer Beyazı grapes. An extra treatment, berry thinning can be applied to Özer Beyazı grapes due to the durability of grapes at the market and transportation conditions through the strong attachment between berry and pedicel. Although $\mathrm{GA}_{3}$ increases the berry weight in Süleymanpaşa Beyazı grapes, berry thinning is necessary after $G_{3}$ spray to obtain the largest berries. On the other hand the higher doses of $\mathrm{GA}_{3}$ can be tried as alternative. Earlier harvest may be possible with in Tekirdağ Misketi grapes. The increase in the crushing resistance of the berries seems like a positive aspect. But the decrease in the berry removal force of the berries can be considered negatively at applications according to control.

\section{Conflicts of Interest}

The authors declare that there is no conflict of interest.

\section{REFERENCES}

Akhmedova A. U. (2020). Effect of gibberellin application for seedless grape varieties of azes breeding. Fruit Growing and Viticulture of South Russia, 61(1), 148-160.

Ateş, F., \& Karabat, S., (2006). Sofralık üzüm üretiminde yaşanan sorunlar ve Sultani Çekirdeksiz üzüm çeşidinde kaliteyi arttırmaya yönelik uygulamalar. Buldan Sempozyumu, Buldan/Denizli, 967-975.

Badr, S. A., \& Ramming, D.W. (1994). The development and response of Crimson Seedless cultivar to cultural practices. Proceedings of the International Symposium on Table Grape Production, Anaheim, 1994, pp. 219222.

ChangHoo, L., DongHyeon, L., H., \& SungBok, K. (1996). Effects of $\mathrm{GA}_{3}$ and Fulmet (KT-30) on fruit set and quality in Kyoho grapes. J. Korean Soc. Hort. Sci., 37(5), 686-690.

Colapietra, M., Tarricone, L., \& Amino, G. (1996). Response to girdling and gibberellic acid. Info. Agra. Supp. 52(50), $17-25$.

Colapietra, M., Tarricone, L., \& Tagliente, G. (1995a). Effect of gibberellic acid and cluster thinning on the qualitative characteristics of table grape Centennial Seedless. Rivista di Frutticoltura e di Ortofloricoltura, 57, 65-70.

Colapietra, M., Tarricone, L., \& Tagliente, G. (1995b). Improving the qualitative characteristics of the seedless cultivar Perlon N. Informatore Agrario, 51(20), 51-56.

Çelik, S. (1998). Bağcılık (Ampeloloji) Cilt:1. Anadolu Matbaa Ambalaj San. ve Tic. Ltd. Şti..

Dardeniz, A. (2014). Effects of cluster tipping on yield and quality of Uslu and Cardinal table grape cultivars. COMU Journal of Agriculture Faculty, 2(1), 21-26.

El-Hammady, A. M., Shaltout, A. D., Abdel-Hamid, N., \& El-Kereamy, A. M. H. (1998). Effect of $\mathrm{GA}_{3}$ treatments on fruit quality of "Flame Seedless" grape cv.. Arab Uni. J. Agri. Sci., 6, 531-542. 
El-Hodairi, M. H., Ibrahim, S. B., Al-Bashir, A. H., Al-Barkouli, A. A., \& Hussein, A. R. (1995). Effect of gibberellic acid on Sultanine Seedless grape variety grown in the Libyan Sahara. Acta Hort., 409, 93-97.

Ergönül, O., Özer, C., \& Özalp, O. Z. (2015). Effects of some plant growth regulator applications on Güz Gülü and Tekirdağ Misketi grape cultivars. Selcuk Journal of Agriculture and Food Sciences, -A 27 (Special Edition of 8. Symposium on Viticulture and Related Technologies in Turkey), 123-128, ISSN:1309-0550.

Fayziev, J. N., Khakimov, A. A., \& Abdullaev, A. N. (2020). The Influence of growth and development regulators on fertility parameters of seedless grape varieties. International Journal of Scientific and Technology Research, 9(3), 1959-1961.

Fidan, Y., Çelik, S., \& Tamer, M. S. (1981). The effect of gibberellic acid and ringing on the accumulation of cellulose in the pedicel and rachis in table grape cultivars. Vignevini, 8(12), 35-39.

Han, W., Han, N., He, X, \& Zhao, X. (2019). Berry thinning to reduce bunch compactness improves fruit quality of Cabernet Sauvignon (Vitis vinifera L.). Scientia Horticulturae, 246,589-596.

Jensen, F. L. (1994). Table grape production in California. Proceedings of the International Symposium on Table Grape Production, Anaheim: 26-30.

Jensen, F. L., Bianchi, M., Moriyama, M., \& Kazarian, D. (1994). Influence of application timing of gibberellin berry enlarging treatments on the maturity of Thompson Seedless table grapes. Proceedings of the International Symposium on Table Grape Production, Anaheim: 47-49.

Kara, Z., \& Ecevit, F. (1998). Study on the effects of gibberellic acid (GA) on the development of different size fruits from some grape cultivars grown in Konya province. Proceedings of IV. Viticulture Symposium, Yalova: $401-$ 408.

Khanduja, S. D., \& Chaturvedi, K. N. (1979). Improving fruit quality in grapes. Indian Horticulture, 24(3), 5-6.

Keskin, N., İşçi B., \& Gökbayrak, Z. (2013). Effects of cane-girdling and cluster and berry thinning on berry organic acids of four Vitis vinifera table grape cultivars. Acta Scientarium Polonorum Hortorum cultus Ogrodnictwo, 12(6), 112-125.

Kukali, E., Thomaj, T., \& Mane, E. (2014). Impact of gibberellins in increasing the production of grape and improving its. Albanian j. Agric.sci., 13, 47-50.

Lavee, S. (1994). Table grape production in Israel. Proceedings of the International Symposium on Table Grape Production, Anaheim: 8-17.

Liuni, C. S., Coletta, A., \& Péres de Souza, L. (1994). Table grape production in Italy. Proceedings of the International Symposium on Table Grape Production, Anaheim: 18-21

Mattheou, A., Stavropoulos, N., \& Samaras, S. (1995). Studies on table germplasm grown in northern Greece, II seedlesness, berry and must characteristics. Vitis, 34(4), 217-220.

Mor, U. S. (1983). Effects of thinning and growth regulators on ripening and quality of grapes (Vitis vinifera L.) cvs. Perlette and Beauty Seedless. J. Thesis Abstracts, Haryana Agricultural University, India.

Moti, D. L. (1971). Effect of plant regulators on ripening and chemical composition of grapes. Punjab Hort. J., 11(3), 194-201.

Nangia, R. P., \& Bakhshi, J.C. (1971). Fruit crop and quality regulation in Perlette variety of vinifera grapes, III Effect of berry-thinning on berry development and fruit quality. J. Research, 8(3), 316-319.

Orth, C. H. F. (1994). Table grape production in South Africa. Proceedings of the International Symposium on Table Grape Production, Anaheim: 22-25

Özer, C., \& Kiracl, M. A. (2002). The relations between some berry characters and berry removal force and berry crushing resistance of table grapes. Proceedings of II. Symposium of Storage and Marketing of Horticultural Products, Çanakkale, 2002, pp. 291-294.

Özer, C., Kiracı, M. A., \& Delice, A. (2002). The study on determination of effects of gibberellic acid and girdling treatments on Barış Grapes. Proceedings of 5. Symposium on Viticulture and Enology in Turkey, Nevşehir,2002, pp. 324-330.

Özer, C., Kiracı, M. A., \& Delice, A. (2005). The effects of Gibberellic Acid and girdling treatments on yield, quality and vine growth at novel table grape cultivars. Proceedings of 6 . Symposium on Viticulture in Turkey, Tekirdağ, 2005, 367-374.

Özer, C., Kiracı, M. A., \& Delice, A. (2008). Some new hybrid table grape cultivars and cultural practices to improve yield and quality. $37^{\text {st }}$ World Congress of Vine and Wine $6^{\text {th }}$ General Assembly of the OIV, June 15-20,2008, P.I.4 Verona, Italy.

Özer, C., Yaşasın, A. S., Ergönül, O., \& Aydın, S. (2012). The effects of berry thinning and gibberellin on Reçel Üzümü table grapes. Pak. J. Agri. Sci., 49(2), 105-112.

Pathare, P. B., Opara, U.L., \& Al-Said, F.J. (2012). Colour Measurement and Analysis in Fresh and Processed Foods: A Review. Food and Bioprocess Technology, 6(1):36-60. DOI: 10.1007/s11947-012-0867-9

Pérez-Harvey, J. (1994). Table grape production in Chile. Proceedings of the International Symposium on Table Grape Production, Anaheim, 1994, pp. 1-7 
Ponce, M. T., Agüero, C.B., Gregori, M.T., \& Tizio, R. (2000). Factors affecting the development of stenospermic grape (Vitis vinifera) embryos cultured in Vitro. Acta Hortic., 528, 667-672.

Roberto, S. R., Mashima, C. H., Colombo, R. C., Assis, A. M., Koyama, R., \& Yukari, L. (2017). Berry-cluster thinning to reduce compactness of 'Black Star' table grapes. Ciência Rural, 47(4), https://doi.org/10.1590/0103$8478 \mathrm{cr} 20160661$

Qadir, A., Wazir, K. H., \& Mehmood, K. (1998). Effect of gibberellic acid on 'Flame Seedless' table grapes in Islamabad. Sarhad J. Agri., 5, 453-455.

Retamales, J., \& Cooper, T. (1993). Berry drop and fruit removal forces as related with $\mathrm{GA}_{3}$ applications in table grapes. Acta Hort. (ISHS), 329:81-83.

Reynolds, A., Price, S., Wardle, D., \& Watson, B. (1994). Fruit environment and crop level effects on Pinot Noir. Vine Performance and Fruit Composition in the British Columbia. Am. J. Enol. Vitic., 45, 452-459.

Saad, F.A., El-Hamady, A.A.M., \& Hamouda, M.M. (1979). Effect of gibberellic acid and ethephon on berry weight, size and quality of Thompson Seedless and Delight grapes. Proc. Saudi Bio. Soc., 3, 45-46.

Samancı, H. (1998). Effect of gibberellic acid on berry and bunch characters of some seedless varieties. Proceedings of IV. Viticulture Symposium, Yalova, 1998, pp 391-394.

Sing, S., Sing, I. S., \& Sing, D. N. (1994). Effect of $\mathrm{GA}_{3}$ on ripening and quality of grape. Orissa J. of Horticulture, 22(1-2), 66-70.

Tian, S., Yong, W., Gang, D., \& Yangxin, L. (2011). Changes in contents and antioxidant activity of phenolic compounds during gibberellin-induced development in vitis vinifera L. 'muscat'. Acta Physiologia Plantarum, 33(6), 2467-2475.

Tavşan, Ö., Dardeniz, A., \& Şahin, E. (2020). The determination of effects of different GA $\mathrm{A}_{3}$ application on grape yield and quality in Sultani Çekirdeksiz grape variety. Turkish Journal of Agricultural and Natural Sciences, 7(4), 1072-1077.

Thilak, K. S. (1983). Effect of gibberellic acid on development and quality of berries of grape cvs. Gulabi and Thompson Seedless (Vitis vinifera L.). J. Thesis Abstracts, HaryanaAgricultural University, 9(1), 62-63.

Uzun, H. I., \& Ceyhan, E. (1995). The researches on effects of gibberellic acid and girdling applications on some cluster and berry characters of Round Seedless grapes. J. Agri. Faculty of Akdeniz University, 8, 52-64.

Wali, V.K., Tiku, A.K., \& Hapa, R. (1990). Response of Perlette grape to gibberellic acid. Advances in Plant Sciences, $3(1), 16-20$.

Yadav, I. S., \& Pandey, S. N. (1974). Effect of berry thinning and gibberellic acid application on the yield and quality of Pusa Seedless grapes (V. vinifera L.). Progressive Hort., 6, (2/3),81-88.

Yong, Y., Jiang-Fei, M., Zhu-Mei, X., \& Zhang, Z. (2016). Effect of GA 3 and CPPU Combined with Different Berry Thinning Methods on 'Summer Black' Grape Quality. Northern Horticulture, 23, 33-39. 